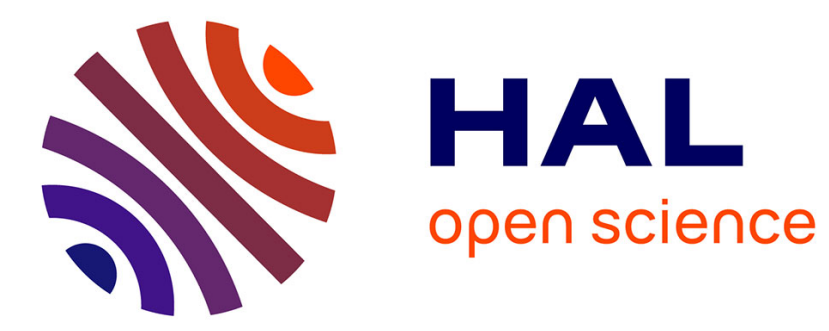

\title{
Temperature induced phase transition of CaMn0.5Zr1.5(PO4)3 phosphate
}

Maria Orlova, Lukas Perfler, Martina Tribus, Petr Salnikov, Benoit Glorieux, Albina Orlova

\section{> To cite this version:}

Maria Orlova, Lukas Perfler, Martina Tribus, Petr Salnikov, Benoit Glorieux, et al.. Temperature induced phase transition of CaMn0.5Zr1.5(PO4)3 phosphate. Journal of Solid State Chemistry, 2016, 235, pp.36-42. 10.1016/j.jssc.2015.12.014 . hal-01253173

\section{HAL Id: hal-01253173 https://hal.science/hal-01253173}

Submitted on 13 Jan 2021

HAL is a multi-disciplinary open access archive for the deposit and dissemination of scientific research documents, whether they are published or not. The documents may come from teaching and research institutions in France or abroad, or from public or private research centers.
L'archive ouverte pluridisciplinaire HAL, est destinée au dépôt et à la diffusion de documents scientifiques de niveau recherche, publiés ou non, émanant des établissements d'enseignement et de recherche français ou étrangers, des laboratoires publics ou privés. 


\title{
Temperature induced phase transition of $\mathrm{CaMn}_{0.5} \mathrm{Zr}_{1.5}\left(\mathrm{PO}_{4}\right)_{3}$ phosphate
}

\author{
Maria Orlova ${ }^{\mathrm{a}, *}$, Lukas Perfler ${ }^{\mathrm{a}}$, Martina Tribus ${ }^{\mathrm{a}}$, Petr Salnikov ${ }^{\mathrm{b}}$, Benoit Glorieux ${ }^{\mathrm{c}}$, \\ Albina Orlova ${ }^{\mathrm{b}}$ \\ a Institute of Mineralogy and Petrography, University of Innsbruck, Innrain 52, Innsbruck 6020, Austria \\ ${ }^{\mathrm{b}}$ Department of Chemistry, University of Nizhny Novgorod, 23 Gagarin Avenue, Nizhny Novgorod 603950, Russia \\ ${ }^{\mathrm{c}}$ CNRS, University of Bordeaux, ICMCB, 87 Albert Schweitzer Avenue, Pessac 33600, France
}

Keywords:

Phosphates

Phase transition

Crystal structure

X-ray powder diffraction

Ab-initio structure solution

\begin{abstract}
A B S T R A C T
In this work we investigated the structural behaviour of a CaMn ${ }_{0.5} \mathrm{Zr}_{1.5}\left(\mathrm{PO}_{4}\right)_{3}$. Due to the presence of divalent $\mathrm{Mn}^{2+}$ cations this compound can possess interesting luminescence properties. It was recently understood that this phosphate undergoes a temperature induced irreversible phase transition in the range of $800875^{\circ} \mathrm{C}$. It has also been shown that the $3 d 3 d$ luminescence of $\mathrm{Mn}^{2+}$ increases 10 fold for the high temperature polymorph. To determine the Mn environment structural investigations of both phases have been performed by the X ray powder diffraction and Raman spectroscopy methods. The low temperature modification adopts the trigonal NZP structure type with a slightly lower symmetry (space group $\left.R 32, a=8.7850(2) \AA, c=22.6496(7) \AA, V=1514.8(1) \AA^{3}\right)$. The high temperature form in turn has orthorhombic symmetry (space group Pnma, $a=6.2350(3) \AA ̊, \quad b=6.6281(3) \AA, \quad c=14.4731(6) \AA$, $\left.V=598.13(5) \AA^{3}\right)$. Both structures were solved $a b$ initio from powder data and structural analysis was performed. In situ and RT Raman spectra are consistent with the XRD derived structural model. $\mathrm{Mn}^{2+}$ cations occupy different types of positions in these structures and a change in $\mathrm{Mn}$ coordination number ( 6 for LT phase, 7 for HT phase) results in different Mn O bond lengths. These differences may explain the change in the optical properties between the polymorphs.
\end{abstract}

\section{Introduction}

$\mathrm{NaZr}_{2}\left(\mathrm{PO}_{4}\right)_{3}(\mathrm{NZP}, \mathrm{NASICON})$ type compounds belong to the large class of $\operatorname{Met}_{m}\left(\mathrm{PO}_{4}\right)_{n}$ phosphates with three dimensional framework structures [1]. Materials of this family show iso and heterovalent isomorphism properties, both in the framework of the structure and in the cavities. Due to cationic/anionic sub stitution it is possible to design compounds with interesting electrical, magnetic, and mechanical properties. Recently, these phosphates have drawn much attention due to their possible ap plication for photodiode technologies since they allow the in corporation of $d$ and $f$ elements which are responsible for luminescence.

Examples of these phosphates include $\mathrm{Eu}^{2+}: \mathrm{Eu}_{0.5} \mathrm{Zr}_{2}\left(\mathrm{PO}_{4}\right)_{3}: \mathrm{Eu}$ [2], $\mathrm{Ca}_{0.5} \mathrm{Zr}_{2}\left(\mathrm{PO}_{4}\right)_{3}: \mathrm{Eu}, \mathrm{Sr}_{0.5} \mathrm{Zr}_{2}\left(\mathrm{PO}_{4}\right)_{3}: \mathrm{Eu}, \mathrm{Ba}_{0.5} \mathrm{Zr}_{2}\left(\mathrm{PO}_{4}\right)_{3}: \mathrm{Eu}$ [3], $\mathrm{Ca}_{0.5}{ }_{x} \mathrm{Eu}_{x} \mathrm{Zr}_{2}\left(\mathrm{PO}_{4}\right)_{3}[4] ; \mathrm{Eu}^{3+}: \mathrm{Eu}_{0.33} \mathrm{Zr}_{2}\left(\mathrm{PO}_{4}\right)_{3}$ [5], $\mathrm{Na}_{3} \mathrm{Al}_{2}\left(\mathrm{PO}_{4}\right) 3$ : $\mathrm{Eu}$ [6], $\mathrm{Ca}_{0.5} \mathrm{Fe}_{1}{ }_{x} \mathrm{Eu}_{x} \mathrm{Sb}\left(\mathrm{PO}_{4}\right)_{3}$ [7], $\mathrm{La}_{1 / 6} \mathrm{~Pb}_{1 / 3} \mathrm{Zr}_{2}\left(\mathrm{PO}_{4}\right)_{17 / 6}\left(\mathrm{SiO}_{4}\right)_{1 / 6}: \mathrm{Eu}$ [8]; $\mathrm{Mn}^{2+}: \quad \mathrm{Na}_{3} \mathrm{Al}_{2}\left(\mathrm{PO}_{4}\right)_{3}: \mathrm{Mn}, \quad \mathrm{Mn}_{0.5} \mathrm{Zr}_{2}\left(\mathrm{PO}_{4}\right)_{3}: \mathrm{Mn}$ [9], $\mathrm{Ca}_{0.4} \mathrm{Mn}_{0.1} \mathrm{Zr}_{2}\left(\mathrm{PO}_{4}\right)_{3}[10]$.

In this work we investigated the structural behaviour of a

\footnotetext{
* Corresponding author.

E-mail address: maria.p.orlova@gmail.com (M. Orlova).
}

$\mathrm{CaMn}_{0.5} \mathrm{Zr}_{1.5}\left(\mathrm{PO}_{4}\right)_{3}$. Due to the presence of divalent $\mathrm{Mn}^{2+}$ cations this compound can possess interesting optical properties. Fur thermore, it has been reported that this compound exists in two polymorphs and that luminescence properties increase drastically (about 10 times) for the high temperature polymorph [11]. In or der to obtain a better understanding of the luminescence me chanism structural investigations of the different polymorphs have been performed. Both structures were solved $a b$ initio from pow der diffraction data using crystal chemical information from si milar phases. The results of this study are presented. The knowl edge obtained could be useful for developing materials with im proved optical properties.

\section{Material and methods}

\subsection{Synthesis}

CaMn ${ }_{0.5} \mathrm{Zr}_{1.5}\left(\mathrm{PO}_{4}\right)_{3}$ was synthesized according to the following procedure: solutions of manganese acetate $\mathrm{Mn}\left(\mathrm{CH}_{3} \mathrm{COO}\right)_{2}(1 \mathrm{M})$ and calcium nitrate $\mathrm{Ca}\left(\mathrm{NO}_{3}\right)_{2}(1 \mathrm{M})$ were added to a solution of zirconium oxychloride $\mathrm{ZrOCl}_{2}(1 \mathrm{M})$, to which solutions of am monium dihydrogen phosphate $\mathrm{NH}_{4} \mathrm{H}_{2} \mathrm{PO}_{4}(1 \mathrm{M})$ and ethylene glycol (1 M) were simultaneously added dropwise to under 
vigorous continuous stirring. The resulting white gel was further stirred under the same conditions for $15 \mathrm{~min}$ and dried at a tem perature of $130{ }^{\circ} \mathrm{C}$ until the moisture was removed (visually). The dried gel (dark brown in colour) was subsequently heated at a temperature of $380^{\circ} \mathrm{C}$ for two days. The black product thus formed was annealed at temperatures of $700,900{ }^{\circ} \mathrm{C}$ for $20 \mathrm{~h}$ at each stage with intermediate careful grinding manually in an agate mortar. LT phase synthesis was finished at $700{ }^{\circ} \mathrm{C}, \mathrm{HT}$ at $900^{\circ} \mathrm{C}$. After final temperature of annealing samples were quenched.

\section{2. $X$ ray diffraction}

$\mathrm{X}$ ray powder diffraction data at ambient conditions were col lected on a STOE STADI MP diffractometer using strictly mono chromatic Cu $\mathrm{K}_{\alpha 1}$ radiation $(\lambda=1.540593 \AA$ ) from a focusing $\mathrm{Ge}$ (111) primary beam monochromator and a Mythen $1 \mathrm{k}$ detector with $11^{\circ}$ detection range, FWHM was equal to $0.048^{\circ}$ at $26.56^{\circ} 2 \theta$. Data acquisition was performed in the range between 8 and $110^{\circ}$ $2 \theta$ with a step size of $0.009^{\circ}$. Measurements were taken in bi secting transmission geometry, with a sample of $2 \mathrm{~mm}$ diameter placed between two zero scattering foils.

\subsection{Raman spectroscopy}

Raman spectra of the polycrystalline phosphates were recorded in the range of $504000 \mathrm{~cm}^{1}$ with a Horiba Jobin Yvon Labram HR 800 Raman microspectrometer. The samples were excited using the $532 \mathrm{~nm}$ emission line of a frequency doubled $25 \mathrm{~mW}$ $\mathrm{Nd}$ :YAG laser and the $633 \mathrm{~nm}$ emission line of a $17 \mathrm{~mW}$ helium neon laser under an Olympus $100 \times$ objective lens (numerical aperture of 0.9). The size of the laser spot on the surface was ap proximately $1 \mu \mathrm{m}$ in diameter. The scattered light was dispersed by an optical grating with 1800 lines $\mathrm{mm}^{1}$ and collected by a $1024 \times 256$ open electrode CCD detector. The spectral resolution, determined by measuring the Rayleigh line, was about $2 \mathrm{~cm} 1$. The accuracy of the Raman line shifts, calibrated by measuring a silicon standard, was in the order of $0.5 \mathrm{~cm}{ }^{1}$. Background and Raman bands were fitted by the built in spectrometer software LabSpec 5 to first or second order polynomials and convoluted Gaussian Lorentzian functions, respectively. The calculation of the number and symmetry of the vibrational modes were carried out using the crystallographic information file and the SAM pro gramme [11 15] . In situ high temperature Raman experiments were performed on a Linkam TS1500 heating stage. The phos phate sample was loaded into the ceramic crucible on a $7 \mathrm{~mm}$ sapphire disc. Measurements were performed from room tem perature up to $1100{ }^{\circ} \mathrm{C}$.

\subsection{Optical analysis}

In order to analyse the possibility of presence of $\mathrm{Mn}^{3+}$ ions, photoluminescence measurement was performed using a spec trofluorimeter SPEX FL212. As mentioned by Mouline et al. [9], the presence of $\mathrm{Mn}^{3+}$ would be revealed by a broad emission band around $800 \mathrm{~nm}$, following an excitation band at $280 \mathrm{~nm}$. No band in this range appeared for the studied compound. Hence, there is no evidence of trivalent manganese in the studied samples.

\subsection{EDS analysis}

In order to confirm the phase composition of synthesized samples and in particular the presence of Mn cations in main phase, EDS examinations has been performed.

EDX data were acquired using a scanning electron microscope (JEOL JSM6010 LV) and a Bruker QUANTAX system equipped with a peltier cooled BRUKER XFlash $410 \mathrm{M}$ silicon drift detector. The powder was placed on double sided sticky carbon tape and coated with a thin conductive carbon layer. The operating conditions for EDX analysis were as follows: $15 \mathrm{kV}$ accelerating voltage, $13.5 \mathrm{~mm}$ working distance, $2900 \mathrm{cps}$ output count rate, 60 s livetime, $2 \%$ deadtime. Semi quantitative (standardless) results were based on a peak to background ZAF evaluation method (P/B ZAF) and a series fit deconvolution model provided by the Esprit 1.9 software (Bruker). Due to the standardless method, the totals are normal ized to $100 \%$. Semi quantitaive analysis gives an atomic ratio of 5.66 at\% Ca, 2.80 at\% Mn, 11.18 at\% Zr, 12.31 at\% P and 68.05 at\% O resulting in a chemical formula of $\mathrm{Ca}_{1.02} \mathrm{Mn}_{0.50} \mathrm{Zr}_{2.01} \mathrm{P}_{2.22} \mathrm{O}$ 12.25. A source of uncertainty in $\mathrm{P}$ and $\mathrm{Zr}$ content can be found in a strong peak overlap between P K series (2.014 $2.142 \mathrm{keV}$ ) and Zr L series (1.792 $2.547 \mathrm{keV})$.

\subsection{Structure solution and refinement}

$\mathrm{CaMn}_{0.5} \mathrm{Zr}_{1.5}\left(\mathrm{PO}_{4}\right)_{3}$ phosphate synthesized at $700{ }^{\circ} \mathrm{C}$ (LT mod ification) adopts a trigonal $R$ centred unit cell similar to that of $\mathrm{NaZr}_{2}\left(\mathrm{PO}_{4}\right)_{3}(R 3 c)$. However, two weak reflections at 11.65 and $12.24^{\circ} 2 \theta$ (Miller indices (003) and (101)), respectively, violate the extinction rule of the $c$ glide plane. Under the assumption of tri gonal symmetry the following five possible space groups remain: $R 3, R 3, R 32, R 3 m, R 3 m$. In the next step, structure solution was initiated in all possible space groups using the parallel tempering algorithm of the FOX programme [16] starting from $\mathrm{Ca}$, and $\mathrm{Zr}$ atoms and rigid $\mathrm{PO}_{4}$ tetrahedra as building blocks. The best relia bility factors were found for the space group $R 32$. The resulting model has been further checked with the ADDSYM routine from the PLATON programme [17]. There were no indications for a hidden higher symmetry.

Following structure solution, the model was refined by the Rietveld method using the FULLPROF.2000 programme [18]. The background was modelled by a set of consecutive points with re fineable intensities. Common isotropic displacement factors were refined for each position. For the allocation of Mn to specific cation sites of $\mathrm{Ca}, \mathrm{Zr} 1$ and $\mathrm{Zr}$, constrained refinement of occupation factor were performed. The sum of two occupation factors (Mn and $\mathrm{Zr}$ or $\mathrm{Mn}$ and $\mathrm{Ca}$ ) was fixed to 1 , but individual values were refined. The result of calculation indicated that $\mathrm{Mn}$ atoms share $\mathrm{Zr} 1$ site $49(\mathrm{Mn}): 51(\mathrm{Zr}) \%$. The refinement of both $\mathrm{Zr}$ sites with fixed mixed occupations of $\mathrm{Mn}$ and $\mathrm{Zr}$ was performed as well in order to check the possibility that Mn atoms can be distributed between both sites, but this led to worse reliability factors. In the following refinement occupation factors were fixed to calculated value.

Incorporation of $\mathrm{Mn}$ atoms into $\mathrm{Zr}$ position led to the split of the site (two $6 c$ sites instead of one $12 c$ in NZP archetype) and, as following, to vanishing of $c$ glide plane. The refinement converged at $R_{B}=3.36 \%, R_{f}=3.98 \%, R_{p}=4.72 \%, R_{w p}=5.94 \%, \chi^{2}=1.4$ (not cor rected for background). Cell parameters and details of the data collection, a list of atomic parameters as well as selected distances can be found in Tables 1 3, respectively. Observed and calculated XRD patterns are shown in Fig. 1a. Small reflections belonging to HT modification (3.8 wt\%) were found and taken into account during calculations.

$\mathrm{CaMn}_{0.5} \mathrm{Zr}_{1.5}\left(\mathrm{PO}_{4}\right)_{3}$ (or $\mathrm{Ca}_{2 / 3} \mathrm{Mn}_{1 / 3} \mathrm{Zr}\left(\mathrm{PO}_{4}\right)_{2}$ ) phosphate synthe sized at $900{ }^{\circ} \mathrm{C}$ (HT phase) was indexed using the TOPAS software package in an orthorhombic cell $\left(6.23 \times 6.62 \times 14.47 \AA^{3}\right)$. Initially, an attempt to use the structure of $\mathrm{CaZr}\left(\mathrm{PO}_{4}\right)_{2}$ (space group $P_{212121}$ ) [19] as an analogue was made. However, a closer look at the re ported fractional coordinates indicated that the structure has been described in an unnecessarily low symmetry. This observation was confirmed when the structure was checked using the MISSYM algorithm implemented in the Platon programme: within a few standard uncertainties the $P_{212121}$ model fulfills the symmetry requirements of the centrosymmetric space group Pnma. 
Table 1

Crystallographic data for LT phase and HT phase of $\mathrm{CaMn}_{0.5} \mathrm{Zr}_{1.5}\left(\mathrm{PO}_{4}\right)_{3}$.

\begin{tabular}{|c|c|c|}
\hline & LT phase & HT phase \\
\hline Chemical formula & $\mathrm{CaMn}_{0.5} \mathrm{Zr}_{1.5}\left(\mathrm{PO}_{4}\right)_{3}^{\mathrm{a}}$ & $\mathrm{Ca}_{0.66} \mathrm{Mn}_{0.33} \mathrm{Zr}\left(\mathrm{PO}_{4}\right)_{2}^{\mathrm{b}}$ \\
\hline $\begin{array}{l}\text { Crystal system, space } \\
\text { group }\end{array}$ & trigonal, R32 (no. 155) & orthorhombic, Pnma (no. 62) \\
\hline$a, \AA$ & $8.7850(2)$ & $6.2350(3)$ \\
\hline$b, \AA$ & $8.7850(2)$ & $6.6281(3)$ \\
\hline$c, \AA$ & $22.6496(3)$ & $14.4731(6)$ \\
\hline$V, \AA^{3}$ & $1514.8(1)$ & $598.13(5)$ \\
\hline$Z$ & 6 & 4 \\
\hline $\begin{array}{l}T_{\text {synthesis }} / T_{\text {data collection }}, \\
{ }^{\circ} \mathrm{C}\end{array}$ & $700 / 25$ & $900 / 25$ \\
\hline$M(\mathrm{~g} / \mathrm{mol})$ & 489.297 & 251.643 \\
\hline$\lambda, \AA$ & 1.54059 & 1.54059 \\
\hline $\mathrm{R}_{b}, \%$ & 3.36 & 5.90 \\
\hline $\mathrm{R}_{w p} \%$ & 5.94 & 11.4 \\
\hline
\end{tabular}

${ }^{\mathrm{a}} R_{f} \quad 3.98 \%, R_{p} \quad 4.72 \%, R_{\exp } \quad 4.82 \%, \chi^{2} \quad 1.41$.

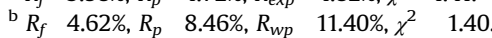

Table 2

Structural XRPD data and details of the structure refinement for the LT modification of $\mathrm{CaMn}_{0.5} \mathrm{Zr}_{1.5}\left(\mathrm{PO}_{4}\right)_{3}$.

\begin{tabular}{|c|c|c|c|c|c|c|}
\hline \multirow[t]{2}{*}{ Atom } & \multicolumn{6}{|c|}{ LT phase } \\
\hline & Site & $x / a$ & $y / b$ & $z / c$ & occ. & $B_{\text {iso }}$ \\
\hline $\mathrm{Ca}$ & $6 c$ & 0 & 0 & $0.2468(4)$ & 1.0 & $3.5(1)$ \\
\hline $\mathrm{Zr} 1$ & $6 c$ & 0 & 0 & $0.8930(1)$ & 0.5 & $1.2(2)$ \\
\hline Mn1 & $6 c$ & 0 & 0 & $0.8930(1)$ & 0.5 & $1.2(2)$ \\
\hline $\mathrm{Zr} 2$ & $6 c$ & 0 & 0 & $0.4011(1)$ & 1.0 & $2.4(2)$ \\
\hline P1 & $9 \mathrm{f}$ & $0.2901(2)$ & 0 & 0 & 1.0 & $2.0(5)$ \\
\hline $\mathrm{P} 2$ & 9f & $0.7054(4)$ & 0 & $1 / 2$ & 1.0 & $1.8(5)$ \\
\hline 01 & $18 \mathrm{f}$ & $0.1634(5)$ & $-0.0298(6)$ & $-0.0508(1)$ & 1.0 & $1.5(5)$ \\
\hline $\mathrm{O} 2$ & $18 \mathrm{f}$ & $0.2896(8)$ & $-0.1725(7)$ & $0.0113(2)$ & 1.0 & $2.5(5)$ \\
\hline $\mathrm{O} 3$ & $18 \mathrm{f}$ & $0.7921(6)$ & $0.0137(7)$ & $0.5622(2)$ & 1.0 & $2.3(5)$ \\
\hline $\mathrm{O} 4$ & $18 \mathrm{f}$ & $0.5273(6)$ & $-0.1540(6)$ & $0.4972(2)$ & 1.0 & $1.2(3)$ \\
\hline
\end{tabular}

atrigonal, $R 32$ (155), $Z \quad 6, a \quad 8.7850(2) \AA ̊, c \quad 22.6496(7) \AA ̊, V \quad$ 1514.8(1) $\AA^{3}$, esd's in parentheses.

In order to obtain an unbiased starting model the crystal structure of the high temperature polymorph was solved from scratch using a global optimization programme FOX, following the same procedure as for low temperature modification. Subse quently, the structure was refined by the Rietveld method using FullProf.2000. During the calculations trials to substitute Ca and $\mathrm{Zr}$ sites with Mn were performed and the occupancy ratio was re fined in the same way as for the LT modification. Successful re finement was obtained for Mn atoms sharing one position of cal cium $(4 c)$ with ratio $66: 33 \%$. The refinement converged at $R_{B}$ $=5.90 \%, R_{f}=4.62 \%, R_{p}=8.46 \%, R_{w p}=11.40 \%, \chi^{2}=1.4$ (not corrected for background). A small impurity (2.66 wt\%) of remaining LT modification was found during the refinement. Details of the data

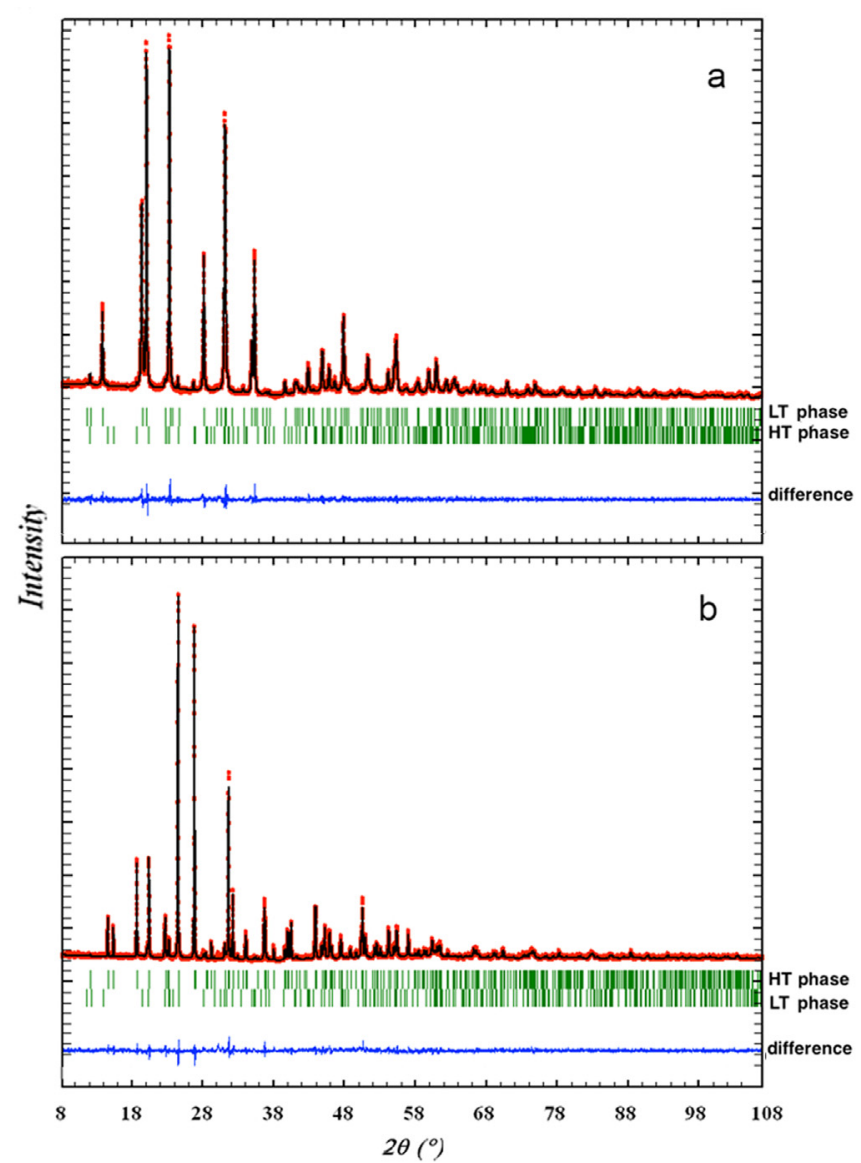

Fig. 1. Observed (points) and calculated (line) XRPD pattern for CaMn ${ }_{0.5} \mathrm{Zr}_{1.5}\left(\mathrm{PO}_{4}\right)_{3}$ : (a) the LT phase of (96.2 wt\%) with minor amounts of HT phase (3.8 wt\%), (b) the HT phase (97.3 wt\%) with minor amounts of LT phase (2.66 wt\%). Vertical bars indicate the positions of the Bragg peaks; the difference pattern is represented at the bottom; CuKa radiation, $\lambda \quad 1.540593 \AA$, $T \quad 25^{\circ} \mathrm{C}$, STOE STADI MP diffractometer, $2 \theta$ range $8-110^{\circ}$, step size $0.009^{\circ}$, data collection time $\sim 16 \mathrm{~h}$.

collection and cell parameters are given in Table 1, list of atomic parameters in Table 4 and selected distances in Table 3, respec tively. Observed and calculated XRD patterns are shown in Fig. 1b.

\subsection{Raman analysis}

From the selection rules of factor group $D_{3}$ (space group $R 32$ ) a total number of 72 vibrational modes are predicted for the trigonal CaMn $_{0.5} \mathrm{Zr}_{1.5}\left(\mathrm{PO}_{4}\right)_{3}$ with the irreducible representations $\Gamma$ $=17 A_{1}+19 A_{2}+36 E$. These calculations on the trigonal unit cell show that 52 modes $\left(17 A_{1}+35 E\right)$ are Raman active while 53 modes $\left(18 \mathrm{~A}_{2}+35 \mathrm{E}\right)$ are IR active; two modes are acoustic $\left(\mathrm{A}_{2}+\mathrm{E}\right)$.

Table 3

Selected interatomic distances $(\AA)$ and angles $\left(^{\circ}\right)$ in the crystal structure of the LT modification of $\mathrm{CaMn}_{0.5} \mathrm{Zr}_{1.5}\left(\mathrm{PO}_{4}\right)_{3}$.

\begin{tabular}{|c|c|c|c|c|c|c|}
\hline \multicolumn{3}{|c|}{ Distance, $\AA$} & \multicolumn{2}{|l|}{ Angle, ${ }^{\circ}$} & \multicolumn{2}{|l|}{ Angle, ${ }^{\circ}$} \\
\hline Ca1 & $\mathrm{O} 4$ & $2.406(8)^{*} 3$ & 01-Zr1IMn1-O1 & $84.9(4)^{*} 3$ & $\mathrm{O} 2-\mathrm{P} 1-\mathrm{O} 2$ & $121.2(2)$ \\
\hline Ca1 & $\mathrm{O} 2$ & $2.757(9) * 3$ & O1-Zr1IMn1-O4 & $98.7(3) * 3$ & $\mathrm{O} 2-\mathrm{P} 1-\mathrm{O} 1$ & $108.1(2) * 2$ \\
\hline Zr1IMn1 & 01 & $2.026(5)^{*} 3$ & O1-Zr1IMn1-04 & $94.2(3)^{*} 3$ & $\mathrm{O} 2-\mathrm{P} 1-\mathrm{O} 1$ & $108.3(2)^{*} 2$ \\
\hline $\mathrm{Zr} 1 \mid \mathrm{Mn} 1$ & 04 & $2.169(4)^{*} 3$ & O4-Zr1IMn1-O4 & $82.3(3) * 3$ & $\mathrm{O} 1-\mathrm{P} 1-\mathrm{O} 1$ & $100.4(2)$ \\
\hline Zr2 & 03 & $2.068(6) * 3$ & $\mathrm{O} 3-\mathrm{Zr} 2-\mathrm{O} 3$ & $104.9(4) * 3$ & $\mathrm{O} 4-\mathrm{P} 2-\mathrm{O} 3$ & $110.8(2) * 2$ \\
\hline $\mathrm{Zr} 2$ & $\mathrm{O} 2$ & $2.076(6)^{*} 3$ & $\mathrm{O} 2-\mathrm{Zr} 2-\mathrm{O} 3$ & $89.1(4)^{*} 3$ & $\mathrm{O} 4-\mathrm{P} 2-\mathrm{O} 4$ & $105.5(2)$ \\
\hline P1 & $\mathrm{O} 2$ & $1.532(4)$ & $\mathrm{O} 2-\mathrm{Zr} 2-\mathrm{O} 3$ & $78.3(4)^{*} 3$ & $\mathrm{O} 4-\mathrm{P} 2-\mathrm{O} 3$ & $100.4(2)^{*} 2$ \\
\hline P1 & 01 & $1.536(4)$ & $\mathrm{O} 2-\mathrm{Ca} 1-\mathrm{O} 2$ & $104.6(2)^{*} 3$ & $\mathrm{O} 3-\mathrm{P} 2-\mathrm{O} 3$ & $127.1(3)$ \\
\hline $\mathrm{P} 2$ & 04 & $1.472(5)$ & O2-Ca1-O4 & $109.7(2)^{*} 3$ & & \\
\hline \multirow[t]{2}{*}{$\mathrm{P} 2$} & 03 & $1.567(2)$ & O4-Ca1-O4 & $115.6(2)^{*} 3$ & & \\
\hline & & & O2-Ca1-O2 & $62.0(3) * 3$ & & \\
\hline
\end{tabular}


Table 4

Structural XRPD data and details of the structure refinement for the HT modification of $\mathrm{Ca}_{0.66} \mathrm{Mn}_{0.33} \mathrm{Zr}\left(\mathrm{PO}_{4}\right)_{2}$.

\begin{tabular}{lllllll}
\hline \multirow{2}{*}{ Atom } & \multicolumn{6}{l}{ HT phase } \\
\cline { 2 - 7 } & Site & $x / a$ & $y / b$ & $z / c$ & $0 c c$. & $B_{\text {iso }}$ \\
\hline Ca & $4 c$ & $0.5550(4)$ & $3 / 4$ & $0.1524(2)$ & $0.66(2)$ & $3.2(2)$ \\
Mn & $4 c$ & $0.5550(4)$ & $3 / 4$ & $0.1524(2)$ & $0.33(2)$ & $2.7(1)$ \\
Zr1 & $4 c$ & $0.8268(2)$ & $1 / 4$ & $0.1102(1)$ & 1.0 & $1.9(4)$ \\
P1 & $4 c$ & $0.5486(3)$ & $3 / 4$ & $0.3823(5)$ & 1.0 & $2.0(8)$ \\
P2 & $4 c$ & $0.3748(3)$ & $1 / 4$ & $0.1484(3)$ & 1.0 & $2.2(8)$ \\
O1 & $4 c$ & $0.1669(8)$ & $1 / 4$ & $0.0951(3)$ & 1.0 & $2.9(8)$ \\
O2 & $8 d$ & $0.5185(4)$ & $0.4255(4)$ & $0.1196(2)$ & 1.0 & $2.3(8)$ \\
O3 & $4 c$ & $0.3262(8)$ & $1 / 4$ & $0.2509(3)$ & 1.0 & $1.5(8)$ \\
O4 & $4 c$ & $0.6766(9)$ & $3 / 4$ & $0.2970(3)$ & 1.0 & $2.3(8)$ \\
O5 & $4 c$ & $0.3953(4)$ & $0.9265(4)$ & $0.3872(3)$ & 1.0 & $2.1(8)$ \\
O6 & $8 d$ & $0.7004(7)$ & $3 / 4$ & $0.4635(3)$ & 1.0 & $1.5(8)$ \\
\hline
\end{tabular}

a orthorhombic, Pnma (62), $Z \quad 4, a \quad 6.2350(3) \AA \AA, b \quad 6.6281(3) \AA ̊, c \quad$ 14.4731(6) $\AA$, $V$ 598.13(5) $\AA^{3}$, esd's in parentheses.

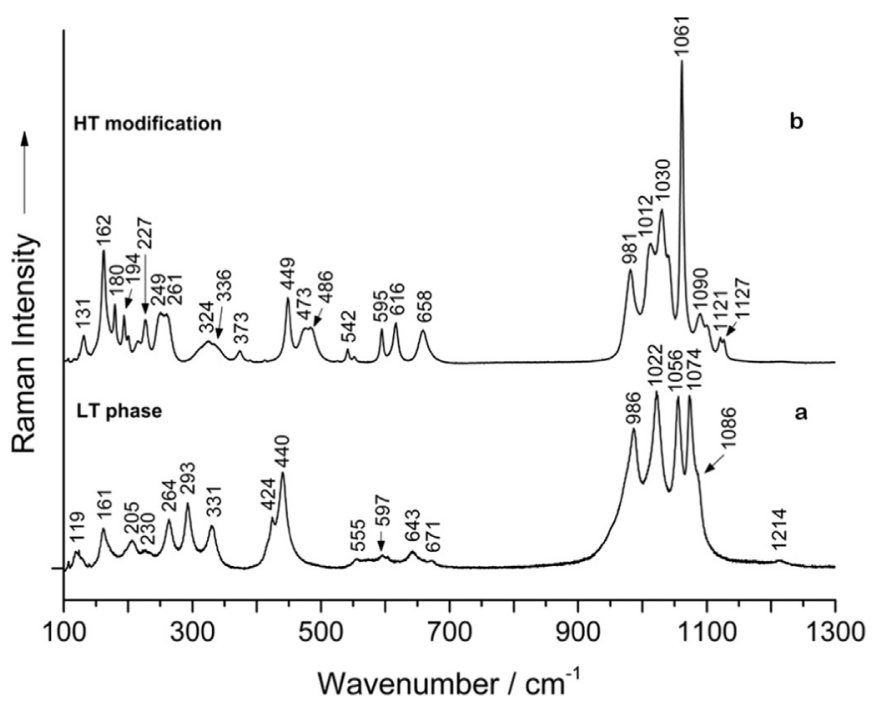

Fig. 2. Raman spectra of polycrystalline CaMn ${ }_{0.5} \mathrm{Zr}_{1.5}\left(\mathrm{PO}_{4}\right)_{3}$ in the region between 100 and $1300 \mathrm{~cm}^{1}$ : (a) low temperature modification and (b) high temperature modification.

On the other hand a total number of 144 vibrational modes are predicted for the orthorhombic $\mathrm{Ca}_{0.66} \mathrm{Mn}_{0.33} \mathrm{Zr}\left(\mathrm{PO}_{4}\right)_{2}$ (factor group $D_{2 h}$, space group Pnma) with the irreducible representations $\Gamma$ $=22 \mathrm{~A}_{\mathrm{g}}+14 \mathrm{~A}_{\mathrm{u}}+14 \mathrm{~B}_{1 \mathrm{~g}}+22 \mathrm{~B}_{1 \mathrm{u}}+22 \mathrm{~B}_{2 \mathrm{~g}}+14 \mathrm{~B}_{2 \mathrm{u}}+14 \mathrm{~B}_{3 \mathrm{~g}}+22 \mathrm{~B}_{3 \mathrm{u}}$. In this case 72 modes $\left(22 \mathrm{~A}_{\mathrm{g}}+14 \mathrm{~B}_{1 \mathrm{~g}}+22 \mathrm{~B}_{2 \mathrm{~g}}+14 \mathrm{~B}_{3 \mathrm{~g}}\right)$ are Raman ac tive while 55 modes are IR active $\left(21 \mathrm{~B}_{1 \mathrm{u}}+13 \mathrm{~B}_{2 \mathrm{u}}+21 \mathrm{~B}_{3 \mathrm{u}}\right)$; three modes are acoustic $\left(B_{1 u}+B_{2 u}+B_{3 u}\right)$. The Raman spectrum of the trigonal CaMn ${ }_{0.5} \mathrm{Zr}_{1.5}\left(\mathrm{PO}_{4}\right)_{3}$ exhibits less visible Raman modes than the Raman spectrum of the orthorhombic high temperature phase because of the high number of doubly degenerated vibrational modes (E type). The Raman spectrum of polycrystalline $\mathrm{CaMn}_{0.5} \mathrm{Zr}_{1.5}\left(\mathrm{PO}_{4}\right)_{3}$ (Fig. 2a, S1 2 (Supporting information)) shows Raman modes with high intensities at 1074, 1056, 1022, 986, $440 \mathrm{~cm}^{1}$, medium modes at 1086, 424, 331, 293, 264, $161 \mathrm{~cm}{ }^{1}$ and weak modes at 1214, 1174, 964, 671, 643, 597, 572, 555, 449, $416,302,230,205,170,139,128,124,119,107 \mathrm{~cm}^{1}$ (Table 5).

On the other hand the Raman spectrum of the high tempera ture modification (Fig. 2b) exhibits strong vibrational modes at 1061(vs), 1042, 1030, 1012, 981, 449, $162 \mathrm{~cm}^{1}$, medium bands at 1090, 658, 616, 595, 486, 473, 261, 249, 227, 194, 180, $131 \mathrm{~cm} \quad 1$ and weak modes at 1127, 1121, 1102, 1065, 986, 664, 552, 542, 412, 390, 373, 336, 324, 316, 214, 201, 172, 154, $107 \mathrm{~cm}{ }^{1}$. Because of the partially overlapping Raman bands, not all of the calculated vibrational modes can be resolved experimentally. Because of the high bond strength and force constants of the $\mathrm{P} O$ bonds ( $\mathrm{P} O$ distances ranging from $1.472 \AA$ and $1.567 \AA$ ), P O stretching vi brations can be observed in the high wavenumber region. All Ra man spectra of phosphates exhibit internal vibrational modes between 900 and $1200 \mathrm{~cm}{ }^{1}$ corresponding to the symmetric $\left(\nu_{1}\right)$ and asymmetric $\left(\nu_{3}\right) \mathrm{P} O$ stretching vibrations of the $\mathrm{PO}_{4}$ tetra hedra. Internal modes involve atomic vibrations of the complex ionic groups that leave their centre of mass stationary; on the other hand external vibrational modes are related to complex ionic groups that vibrate as rigid units [20]. Symmetric and asymmetric $\mathrm{O} \mathrm{P} O$ bending vibrations $\left(\nu_{s}\right.$ and $\left.\nu_{4}\right)$ occur in the wavenumber region between 400 and $680 \mathrm{~cm}^{1}$. Raman bands below $400 \mathrm{~cm}^{1}$ are caused mainly by complex vibrations involving the metal atoms $\left(\mathrm{M}=\mathrm{Ca}^{2+}, \mathrm{Mn}^{2+}, \mathrm{Zr}^{4+}\right)$ and rotational modes of the $\mathrm{PO}_{4}$ units at the very low frequency region (external modes).

In situ high temperature Raman spectra reveals that phase transition takes place in the range from 800 to $875^{\circ} \mathrm{C}$ (Fig. 3). The most noticeable changes occur in the wavenumber range $220400 \mathrm{~cm}^{1}, 550750 \mathrm{~cm}^{1}$ and between 900 and $1100 \mathrm{~cm}^{1}$.

\section{Results and discussion}

Despite the different space groups ( $R 32$ instead of $R 3 c$ ), the crystal structure of the low temperature polymorph still retains the main features of the NZP type structure. The Mn atoms share the framework site Zr1 (Wyckoff position 6c) with a site

Table 5

Selected interatomic distances $(\AA)$ in the crystal structure for HT modification of $\mathrm{Ca}_{0.66} \mathrm{Mn}_{0.33} \mathrm{Zr}\left(\mathrm{PO}_{4}\right)_{2}$.

\begin{tabular}{|c|c|c|c|c|c|}
\hline Distance, Å & & Angle, ${ }^{\circ}$ & & Angle, ${ }^{\circ}$ & \\
\hline CalMn $\mathrm{O} 2$ & $2.213(4)^{*} 2$ & O2-CalMn-O2 & 152.31(16) & O4-P1-05 & $112.9(2)^{*} 2$ \\
\hline CalMn 04 & $2.226(8)$ & O2-CaIMn-O4 & $103.64(14) * 2$ & O4-P1-O6 & $108.1(6)$ \\
\hline CalMn 04 & $2.470(6)$ & O2-CalMn-O4 & $87.73(14)^{*} 2$ & O5-P1-O5 & $101.3(2)$ \\
\hline CalMn 05 & $2.490(5)^{*} 2$ & O2-CalMn-O5 & $119.97(17)^{*} 2$ & O5-P1-06 & $110.8(2)^{*} 2$ \\
\hline CalMn 06 & $2.777(8)$ & O2-CalMn-O5 & $65.46(18) * 2$ & $\mathrm{O} 3-\mathrm{P} 2-\mathrm{O} 1$ & $109.9(5)$ \\
\hline $\mathrm{Zr} \mathrm{O} 3$ & $2.008(10)$ & O2-CalMn-O6 & $77.63(14)^{*} 2$ & $\mathrm{O} 3-\mathrm{P} 2-\mathrm{O} 2$ & $112.7(2)^{*} 2$ \\
\hline $\mathrm{Zr} \mathrm{O6}$ & $2.128(8)$ & O4-CalMn-O4 & $92.5(2)$ & $\mathrm{O} 1-\mathrm{P} 2-\mathrm{O} 2$ & $111.2(2)^{*} 2$ \\
\hline $\mathrm{Zr} \mathrm{O} 1$ & $2.130(10)$ & O4-CalMn-O5 & $86.97(15)^{*} 2$ & $\mathrm{O} 2-\mathrm{P} 2-\mathrm{O} 2$ & $99.3(2)$ \\
\hline $\mathrm{Zr} \mathrm{O5}$ & $2.186(5)^{*} 2$ & O4-CalMn-O5 & $151.83(11)^{*} 2$ & & \\
\hline $\mathrm{Zr} \mathrm{O} 2$ & $2.252(5)^{*} 2$ & O4-CalMn-O6 & $53.9(2)$ & & \\
\hline P1 O4 & $1.453(10)$ & O5-CalMn-O6 & $122.92(11)^{*} 2$ & & \\
\hline P1 O5 & $1.514(5)^{*} 2$ & O5-CalMn-O5 & $56.20(16)$ & & \\
\hline P1 O6 & $1.514(10)$ & O4-CaIMn-O6 & $146.5(2)$ & & \\
\hline P2 O3 & $1.512(11)$ & & & & \\
\hline P2 01 & $1.513(10)$ & & & & \\
\hline P2 O2 & $1.521(5)^{*} 2$ & & & & \\
\hline
\end{tabular}




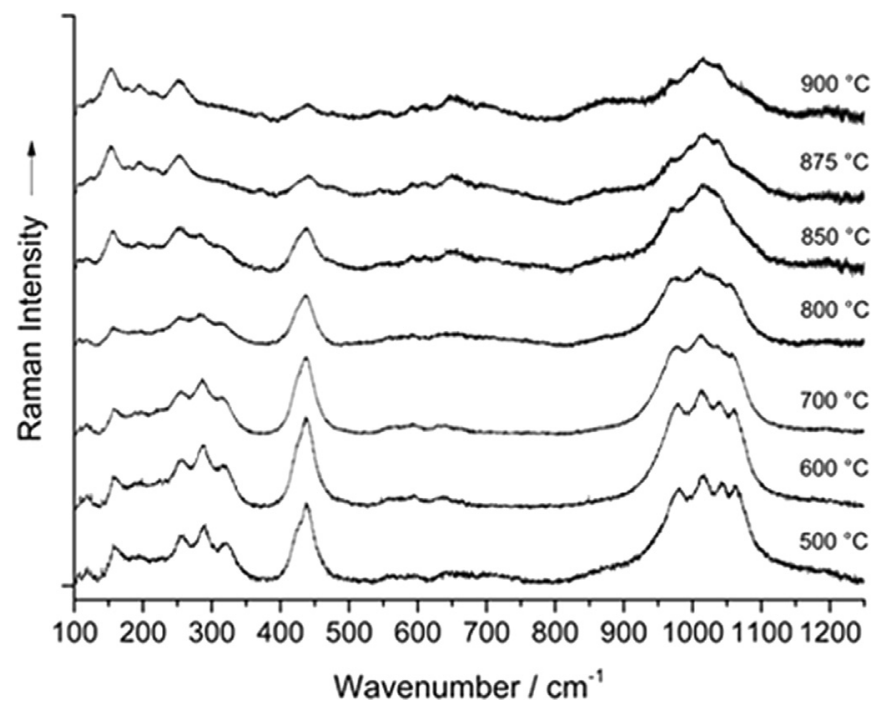

Fig. 3. In situ high temperature Raman spectra of $\mathrm{CaMn}_{0.5} \mathrm{Zr}_{1.5}\left(\mathrm{PO}_{4}\right)_{3}$ measured in the range from 500 up to $900{ }^{\circ} \mathrm{C}$.

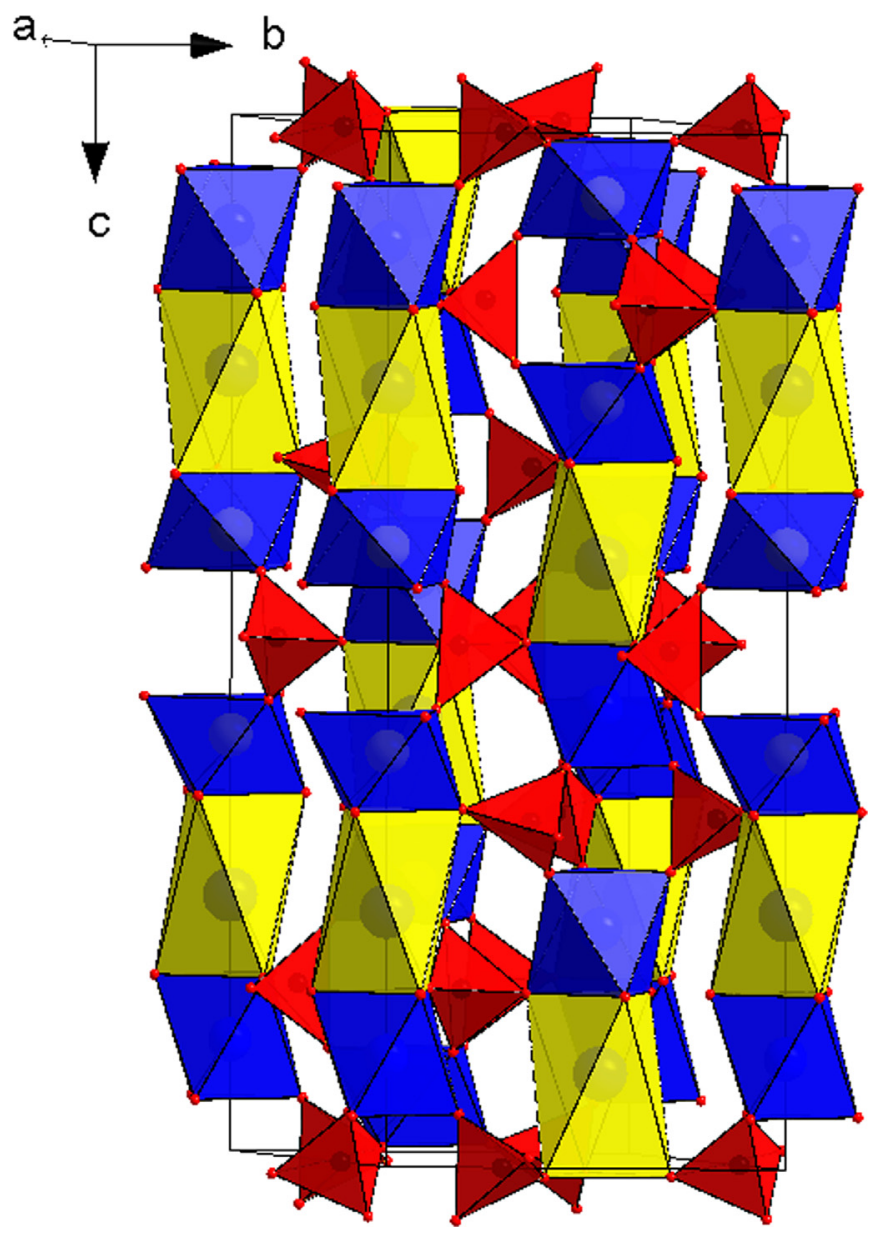

Fig. 4. Structure of trigonal LT modification of $\mathrm{CaMn}_{0.5} \mathrm{Zr}_{1.5}\left(\mathrm{PO}_{4}\right)_{3}$.

population of $49 \%$ for $\mathrm{Mn}$ and $51 \%$ for $\mathrm{Zr}$. The $6 c$ position of $\mathrm{Zr} 2$ in turn is fully occupied with $\mathrm{Zr}$ atoms. Both $\mathrm{Zr} / \mathrm{Mn}$ and $\mathrm{Ca}$ atoms are six fold coordinated. $\mathrm{Ca} \mathrm{O}$ and $\mathrm{Zr} / \mathrm{Mn} \mathrm{O}$ bond lengths are con sistent with those reported for $\mathrm{NaZr}_{2}\left(\mathrm{PO}_{4}\right)_{3}[1], \mathrm{Ca}_{0.5} \mathrm{Zr}_{2}\left(\mathrm{PO}_{4}\right)_{3}[21]$
Table 6

Selected average interatomic distances $(\AA)$ in the crystal structures of LT and HT phase of $\mathrm{CaMn}_{0.5} \mathrm{Zr}_{1.5}\left(\mathrm{PO}_{4}\right)_{3}$ (present work), $\mathrm{Ca}_{0.5} \mathrm{Zr}_{2}(\mathrm{PO} 4)_{3}$ [21] and $\mathrm{Mn}_{0.5}$ $\mathrm{Zr}_{2}\left(\mathrm{PO}_{4}\right)_{3}[9]$.

\begin{tabular}{|c|c|c|c|c|c|c|c|}
\hline \multicolumn{2}{|c|}{$\begin{array}{l}\mathrm{CaMn}_{0.5} \mathrm{Zr}_{1.5}\left(\mathrm{PO}_{4}\right) \\
\text { (LT) }\end{array}$} & \multicolumn{2}{|c|}{$\begin{array}{l}\mathrm{CaMn}_{0.5} \mathrm{Zr}_{1.5}\left(\mathrm{PO}_{4}\right) \\
(\mathrm{HT})\end{array}$} & \multicolumn{2}{|c|}{$\mathrm{Ca}_{0.5} \mathrm{Zr}_{2}\left(\mathrm{PO}_{4}\right)_{3}$} & \multicolumn{2}{|c|}{$\mathrm{Mn}_{0.5} \mathrm{Zr}_{2}\left(\mathrm{PO}_{4}\right)_{3}$} \\
\hline $\mathrm{Ca}-\mathrm{O}, a v$ & $2.587 \AA$ & $\begin{array}{l}\mathrm{Ca} / \mathrm{Mn}- \\
\mathrm{O}, \mathrm{av}\end{array}$ & $2.417 \AA$ & $\mathrm{Ca}-\mathrm{O}, a v$ & $2.49 \AA$ & $\mathrm{Mn}-\mathrm{O}, a v$ & $2.31 \AA$ \\
\hline $\begin{array}{l}\mathrm{Zr} / \mathrm{Mn}- \\
\mathrm{O}, \text { av }\end{array}$ & $2.084 \AA$ & $\mathrm{Zr}-\mathrm{O}, a v$ & $2.159 \AA$ & $\mathrm{Zr}-\mathrm{O}, a v$ & $2.16 \AA$ & $\mathrm{Zr}-\mathrm{O}, a v$ & $2.06 \AA$ \\
\hline $\mathrm{P}-\mathrm{O}, a v$ & $1.527 \AA$ & $\mathrm{P}-\mathrm{O}, a v$ & $1.508 \AA$ & $\mathrm{P}-\mathrm{O}, a v$ & $1.52 \AA$ & $\mathrm{P}-\mathrm{O}, a v$ & $1.56 \AA$ \\
\hline
\end{tabular}
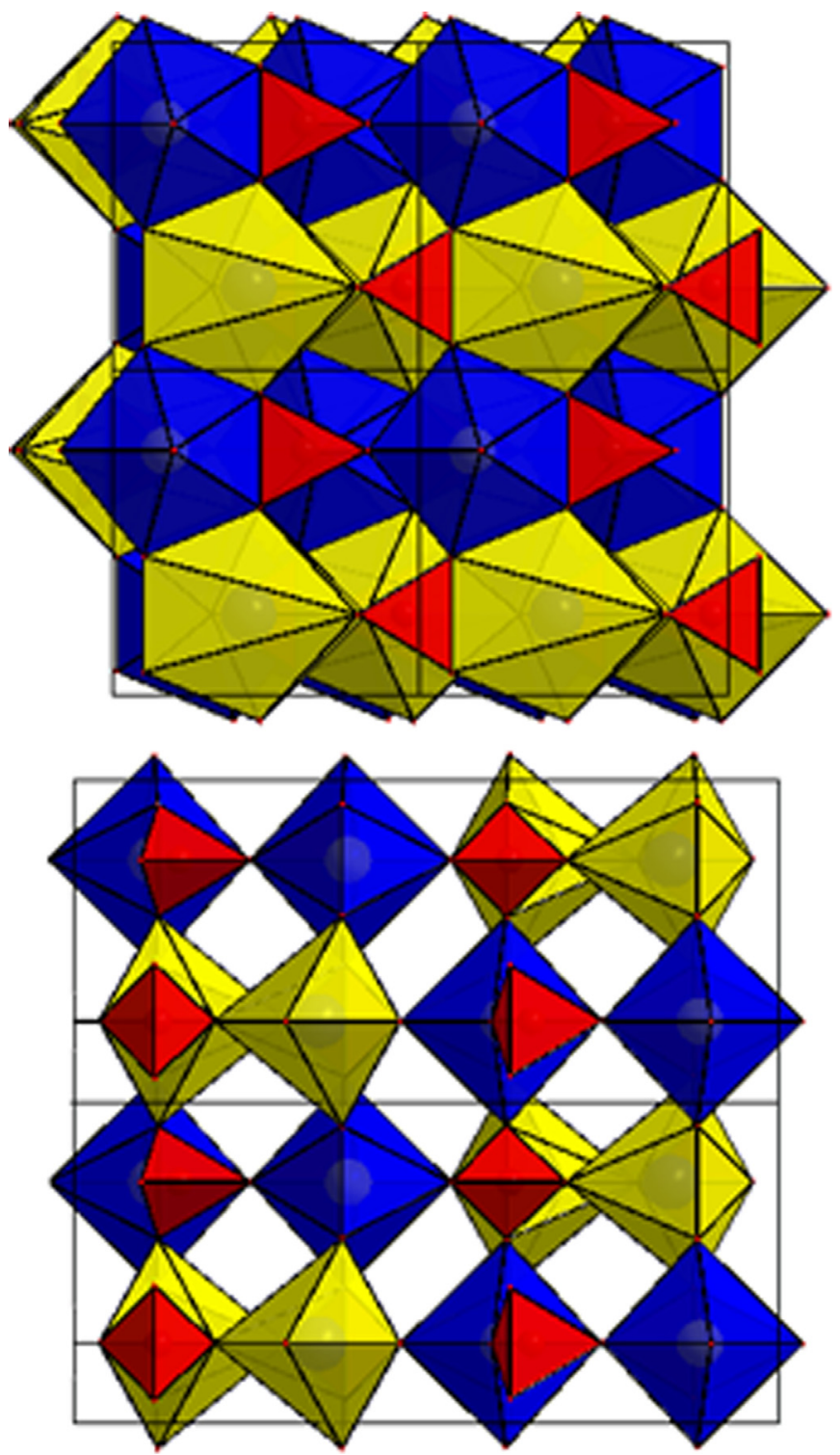

Fig. 5. The crystal structure of HT modification $\mathrm{CaMn}_{0.5} \mathrm{Zr}_{1.5}\left(\mathrm{PO}_{4}\right)_{3}$ viewed along (top) [001] and (bottom) [100] directions showing the three-dimensional framework.

and $\mathrm{Mn}_{0.5} \mathrm{Zr}_{2}\left(\mathrm{PO}_{4}\right)_{3}$ [9]. $\mathrm{Zr} / \mathrm{Mn} \mathrm{O} \mathrm{O}_{6}$ and $\mathrm{PO}_{4}$ polyhedra are slightly distorted, e.g. the $\mathrm{P} O \mathrm{O}$ distances are in the range $1.4721 .567 \AA$ (mean $1.527 \AA$ ) (Table 4). The structure contains a 3D framework of corner sharing $\mathrm{Zr} / \mathrm{MnO}_{6}$ octahedra and $\mathrm{PO}_{4}$ tetrahedra. $\mathrm{Ca}$ atoms completely fill one kind of cavity in the structure. Structural 

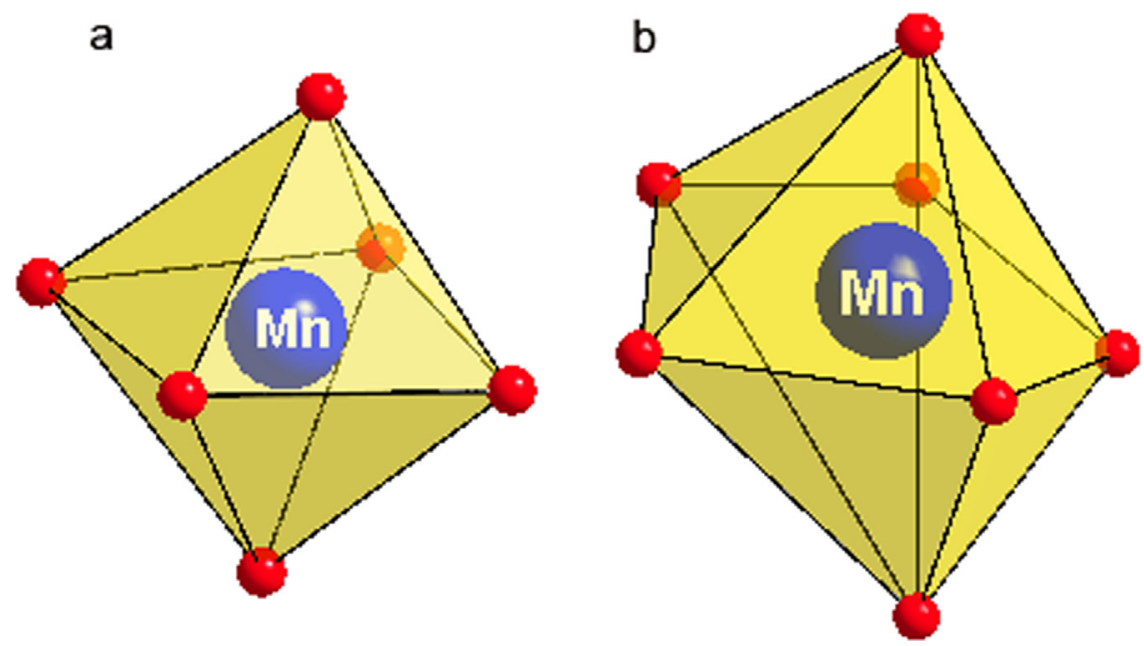

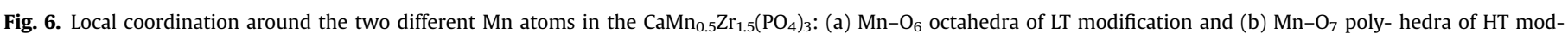
ification.

units consisting of two octahedra and three tetrahedra are con nected to form ribbons parallel to the $c$ axis. These ribbons are linked together perpendicular to the $c$ direction by tetrahedra to build a three dimensional framework (Fig. 4).

Despite different space groups (Pnma instead of $P_{212121}$ ), the crystal structure of the orthorhombic high temperature poly morph still retains the main features of the $\mathrm{CaZr}\left(\mathrm{PO}_{4}\right)_{2}$ structure [21]. The $\mathrm{Zr}$ atom is sevenfold coordinated with a mean $\mathrm{Zr} O$ distance of $2.158 \AA$, which is comparable to that of the $\mathrm{ZrO}_{7}$ polyhedron (2.16 $\AA$ ) in dizirconium oxophosphate $\mathrm{Zr}_{2} \mathrm{O}\left(\mathrm{PO}_{4}\right)_{2}$ [22]. $\mathrm{Mn}^{2+}$ cation share seven fold coordinated position $4 c$ with $\mathrm{Ca}^{2+}$ with occupancies of $33 \% \mathrm{Mn}$ and $66 \% \mathrm{Ca}$. The $\mathrm{Ca} / \mathrm{Mn} \mathrm{O}$ distance $(2.417 \AA)$ is consistent with the weighted sum of their ionic radii according to Shannon [23]. $\mathrm{PO}_{4}$ polyhedra are distorted; the $\mathrm{P} O$ distances are in the range $1.4531 .521 \AA$ (mean $1.508 \AA$ ) (Table 4) which is in good agreement with the average value of $1.537 \AA$ found in the literature for the phosphates [24]. (Table 6)

The crystal structure of the high temperature modification consists of $\mathrm{Ca} / \mathrm{MnO}_{7}, \mathrm{ZrO}_{7}$ and $\mathrm{PO}_{4}$ polyhedra. They share edges and form infinite chains along the $b$ direction (Fig. 5a). Individual chains are linked via oxygen atoms and form two dimensional layers (Fig. 5b). These layers are linked with neighbouring sheets in the $c$ direction via oxygen atoms (4 layers per unit cell) resulting in the formation of a three dimensional structure.

The rhombohedral structure of LT modification changes to an orthorhombic cell with the following change in space group from R32 to Pnma. Due to reconstructive nature of structural changes and co existence of both modification at broad temperature in terval, we conclude that compound undergoes 1 st order phase transition. $\mathrm{Mn}^{2+}$ cations occupy different types of positions in the studied structures. In the LT phase Mn shares the framework po sition $6 c$ with $\mathrm{Zr} 1$, in the HT phase Mn shares $4 c$ position with $\mathrm{Ca}$. Therefore, Mn coordination is changed drastically. In the LT modification it has octahedral coordination and $\mathrm{Zr} / \mathrm{Mn} \mathrm{O}$, av is $2.097 \AA$, in the HT modification $\mathrm{Mn}^{2+}$ cations have seven fold coordination and $\mathrm{Ca} / \mathrm{Mn} \mathrm{O}$, av $2.417 \AA$ (Fig. 6).

\section{Conclusions}

The results of this work show that $\mathrm{Mn}^{2+}$ cations occupy dif ferent types of positions in low and high temperature poly morphs of $\mathrm{CaMn}_{0.5} \mathrm{Zr}_{1.5}\left(\mathrm{PO}_{4}\right)_{3}$. A change in coordination number of
Mn (6 for LT phase, 7 for HT phase) results in a change of Mn $\mathrm{O}$ bond lengths (Mn O, $a v .=2.084 \AA$ for LT phase, Mn O, $a v .=2.417 \AA$ for HT phase).

These structural changes provide one possible explanation for the observed significant change in optical properties. In order to better understand the mechanism of luminescence we intend to further investigate the optical properties of the studied compound in light of the structural information here presented.

\section{Aknowlegements}

We thank Volker Kahlenberg and Gilles Wallez for valuable crystallographic corrections, Roberto Nervo and Michael Reynolds for proofreading. The financial support of the Ministry of Educa tion and Science of the Russian Federation (Project no. $11.1036 .2014 / \mathrm{K})$ is gratefully acknowledged.

\section{Appendix A. Supplementary material}

Supplementary data associated with this article can be found in the online version at doi:10.1016/j.jssc.2015.12.014.

\section{References}

[1] L. Hagman, P. Kierkegaard, Acta Chem. Scand. 22 (1968) 1822.

[2] T. Masui, K. Koyabu, S. Tamura, N. Imanaka, J. Zhang, J. Alloy. Compd. 418 (2006) 73-76.

[3] M. Hirayama, N. Sonoyama, A. Yamada, R. Kanno., J. Solid State Chem. 182 (2009) 730-735.

[4] B. Glorieux, V. Jubera, A. Orlova, A. Kanunov, A. Garcia, C. Pallier, T. Oleneva, Inorg. Mater. 49 (1) (2013) 82-88.

[5] M.P. Saradhi, V. Pralong, U.V. Varadaraju, B. Raveau, Chem. Mater. 21 (2009) 1793-1795.

[6] I.M. Nagpure, K.N. Shinde, V. Kumar, J. Alloy. Compd. 492 (2010) 384-388.

[7] N. Semi, Solid State Ion. 181 (2010) 659-663.

[8] K. Bakhous, F. Cherkaoui, A. Nenabad, J.M. Savariault, Mater. Res. Bull. 34 (2) (1999) 263-269.

[9] A. Mouline, M. Alami, R. Brochu, R. Olazcuaga, C. Parent, G. Le Flem, Mater. Res. Bull. 35 (2000) 899-908.

[10] B. Glorieux, A. Orlova, A. Garcia, A. Kanunov, V. Jubera, "CIMTEC-2010" Book of Abstracts, (2010) 100-101.

[11] M. Orlova, B. Glorieux, A. Orlova, P. Salnikov, V. Kahlenberg, EPDIC13, Book of Abstracts, (2012) 136.

[12] M.I. Aroyo, J.M. Perez-Mato, D. Orobengoa, E. Tasci, G. Flor, A. Kirov, Bulg. Chem. Commun. 43 (2) (2011) 183-197. 
[13] M.I. Aroyo, J.M. Perez-Mato, C. Capillas, E. Kroumova, S. Ivantchev, G. Madariaga, A. Kirov, H. Wondratschek, Z. Kristallogr. 221 (1) (2006) 15-27.

[14] M.I. Aroyo, A. Kirov, C. Capillas, J.M. Perez-Mato, H. Wondratschek, Acta Crystallogr. A62 (2006) 115-128.

[15] E. Kroumova, M.I. Aroyo, J.M. Perez-Mato, A. Kirov, C. Capillas, S.H. Ivantchev, Phase Transit. 76 (2003) 155-170.

[16] V. Favre-Nikolin, R. Cerny, Mater. Sci. Forum (2004) 443-444.

[17] A.L. Spec., PLATON, University of Utrecht, The Netherlands, 2006.

[18] J. Rodriguez-Carvajal, Journal of recent developments of the program FULLPROF, in commission on powder diffraction (IUCr), Newsletter 26 (2001) 12-19.
[19] K. Fukuda, K. Fukutani, Powder Diffr. 18 (4) (2003) 296-300.

[20] P.N. de Aza, C. Santos, A. Pazo, S. de Aza, R. Cusco, L. Artús, Chem. Mater. 9 (1997) 912-915.

[21] W. Fischer, L. Singheiser, D. Basu, A. Dasgupta, Powder Diffr. 19 (2) (2004) $153-156$.

[22] W. Gebert, E. Tillmanns, Acta Crystallogr. B 31 (1975) 1768-1770.

[23] R.D. Shannon, Acta Crystallogr. A32 (1976) 761-767.

[24] W.H. Baur, Acta Crystallogr. B30 (1974) 1195-1215. 